\title{
Factors associated with leprosy in a municipality of the Pre- Amazon region, state of Maranhão, Brazil
}

\author{
Antônio Rafael da Silva[ ${ }^{[1],[2]}$, Pedro Martins Lima Neto ${ }^{[2],[3], ~ L e o n a r d o ~ H u n a l d o ~ d o s ~ S a n t o s ~}{ }^{[3]}$, \\ Raina Jansen Cutrim Propp Lima ${ }^{[4]}$, Pedro Luiz Tauil ${ }^{[5]}$ \\ and Eloísa da Graça do Rosário Gonçalves ${ }^{[1],[2]}$
}

[1]. Centro de Referência em Doenças Infecciosas e Parasitárias, Departamento de Patologia, Universidade Federal do Maranhão, São Luís, MA, Brasil.

[2]. Programa de Pós-Graduação em Saúde e Ambiente, Universidade Federal do Maranhão, São Luís, MA, Brasil.

[3]. Centro de Ciências Sociais, Saúde e Tecnologia, Universidade Federal do Maranhão, Imperatriz, MA, Brasil.

[4]. Departamento de Ensino, Instituto Federal de Educação, Ciência e Tecnologia do Maranhão. Açailândia, MA, Brasil. [5]. Programa de Pós-Graduação em Medicina Tropical, Universidade de Brasília, Brasília, DF, Brasil.

\begin{abstract}
Introduction: The Integrated Program of Leprosy Control was initiated in the municipality of Buriticupu, Maranhão, Brazil, an area considered hyperendemic for leprosy in 2003. It aims at assessing the clinical and epidemiological characteristics of the disease to reduce the detection rate of new cases until 2015. Here, we present the evolution of the indicators of leprosy within the period from 2003 to 2015. Methods: We conducted a descriptive analytical study based on the active search for and voluntary referral of cases of leprosy. The detection rate of new cases was analyzed over time. We included individuals diagnosed with leprosy between January 2003 and December 2015. The association between categorical variables was assessed using the chisquare test of independence, considering a level of significance of $5 \%$. When the association was significant, the detection rate (with a confidence interval of 95\%) was calculated. Results: Overall, 879 new leprosy cases were detected; the majority of the affected individuals were men (65.9\%). Multibacillary leprosy was the most common type of the disease, according to the operational classification (55.5\%); it showed the strongest association with an age $\geq 60$ years. We also detected an association between the male sex and both, lepromatous and multibacillary leprosy. The detection rate reduced from 211.09/100,000 population in 2003 to 50.26/100,000 population in 2015. Conclusions: We found an improvement in leprosy control, with a reduction in the detection rate and the absolute number of cases. Strengthening of disease control measures should be prioritized to eliminate leprosy as a public health concern in this municipality.
\end{abstract}

Keywords: Leprosy. Mycobacterium leprae. Health profile. Detection rate. Epidemiological case-series.

\section{INTRODUCTION}

Leprosy is one of the oldest diseases in the history of humanity, with case reports existing since Biblical times. Records show that the disease was introduced into the American continent in the mid- $16^{\text {th }}$ century by European immigrants and later by African slaves ${ }^{1}$. Leprosy is an infectious, contagious disease caused by the intracellular bacillus Mycobacterium leprae. Its major clinical manifestations are skin and neurological injuries that may lead to the onset of physical incapacities and psychosocial limitations ${ }^{2}$.

There is a great disparity in the geographic distribution of leprosy, and cases are concentrated in only a few countries. Recently, the World Health Organization (WHO) established a

Corresponding author: Dr. Antônio Rafael da Silva.

e-mail: credip@ufma.br

Received 19 February 2018

Accepted 8 October 2018 strategy for leprosy elimination by 2020 . The strategy aims at a zero diagnosis of leprosy or physical disabilities among children, no countries without specific legislation against discrimination, and a detection rate of $<1$ case per 1 million persons ${ }^{3}$.

Brazil has the second-highest number of notified cases worldwide and accounting for $91.93 \%$ of leprosy cases in America in $2014^{4}$. In 2014, the prevalence of leprosy was 1.27 cases per 10,000 population $(25,738$ cases under treatment), and the detection rate was 15.32 cases per 100,000 population (31,064 new cases). According to official parameters, this defines Brazil as a country with high endemicity 5 .

Regarding the Brazilian states, in 2014, Mato Grosso had 82.03 leprosy cases per 100,000 population, followed by Tocantins and Maranhão with 69.88 and 53.02 cases per 100,000 population, respectively. Maranhão had the thirdhighest detection rate for new cases, with 3,632 cases detected in 2014 , accounting for $11.69 \%$ of all cases detected in Brazil. The epidemiological indicators in the municipality of Buriticupu, Maranhão classify are classified as hyperendemic for leprosy because of the high detection rates ${ }^{6}$. 
This study is the result of an intervention targeting leprosy control in the municipality of Buriticupu that was initiated in 2003 by the Integrated Control of Leprosy Project, targeting school-aged children and the general population ${ }^{7-9}$. The aim of the project was to reduce the incidence of the disease by assessing demographic, epidemiological, and clinical features of leprosy in Buriticupu .

\section{METHODS}

This was a case-series epidemiological study based on voluntary referral of and active search for cases of leprosy. We analyzed the leprosy detection rates and number of new cases between January 2003 and December 2015. The data were collected from the Database of the Center of Studies in Tropical Medicine of the Federal University of Maranhão, municipality of Buriticupu (located in the western part of the state of Maranhão), Pre-Amazon region of Maranhão.

A suspicion of leprosy was based on alterations in skin color and/or sensitivity 5 . Bacilloscopy of intradermal scrapings was performed in all suspected patients and interpreted according to the criteria established by Ridley and Jopling in $1962^{10}$. Lesions were histologically examined when the definition of the clinical type of leprosy was unclear.

The primary variables analyzed in this case study included the age group $(<15$ years / 15 to 19 years / 20 to 29 years / 30 to 39 years / 40 to 49 years / 50 to 59 years / $\geq 60$ years), sex, operational classification (paucibacillary or multibacillary leprosy) as proposed by the $\mathrm{WHO}^{11}$, clinical type, and origin of the infection. The clinical types were defined as indeterminate, tuberculoid, dimorphous or borderline, and lepromatous according to the Madrid classification ${ }^{12}$.

The collected data were stored in a database that was created using Microsoft Excel 2016 (Software Foundation, Inc., 51 Franklin Street, Fifth Floor, Boston, MA 02110-1301, USA). Statistical analysis was performed using the IBM SPSS software (IBM's Corporate Privacy Office 1 New Orchard Road Armonk, NY 10540 U.S.A.) after checking for errors and inconsistencies ${ }^{13}$. Quantitative variables are expressed as absolute and relative frequencies. The associations between the categorical variables were assessed using the chi-square $\left(\chi^{2}\right)$ test of independence ${ }^{14}$. The level of significance was set at $5 \%$ and a confidence interval of $95 \%(95 \% \mathrm{CI})^{15}$. We analyzed the associations between age group and operational classification, between sex and clinical type, and between sex and operational classification.

In compliance with the requirements of Resolution 466/2012 of the Brazilian National Health Council following the Guidelines and Rules for Research Involving Humans, the present study was approved by the Research Ethics Committee of the Universidade Federal do Maranhão under no. 234.767, protocol no. 12700713.9.0000.5084.

\section{RESULTS}

The study analyzed 879 new cases of leprosy (65.9\% were men and $34.1 \%$ women); of these cases, $21.5 \%$ of the individuals were aged between 20 and 29 years. According to the operational classification, $55.5 \%$ of the patients had multibacillary leprosy; the most frequent clinical types of leprosy were dimorphous (32.1\%) and tuberculoid (24.9\%) (Table 1).

We found a statistically significant association between the operational type and age group $(\mathrm{p}<0.001)$. The incidence of the paucibacillary type decreased with increasing age (the detection rate of the paucibacillary type was 2.43 times higher in individuals $<15$ years old than in those aged $\geq 60$ years; Table 2). We also detected a reduction in the number of cases recorded in individuals aged $<15$ years of age between 2010 and 2015 .

Male sex and the multibacillary type exhibited an even stronger association $(p<0.001$; Table 3$)$. The probability of the multibacillary type was almost two times higher in men than in women (detection rate [DR] 1.64, 95\% confidence interval [95\% CI] 1.41-1.92; Table 3). There was a higher proportion of leprosy cases of all clinical types in men $(p<0.001)$; this was particularly evident for the dimorphous and lepromatous types, for which men accounted for $74.5 \%$ and $78.5 \%$ of cases, respectively. Regarding DRs, the lepromatous and dimorphous types were 1.56 and 1.48 times more common in men than the indeterminate type (Table 4).

This study showed a significant reduction in the number of cases of leprosy over time and a decreasing trend in the annual detection rate per 100,000 population. However, the municipality remained hyperendemic throughout the assessed period, as evidenced by the historical series that showed the highest rate of cases in 2003 (DR 211.09/100,000 population; 116 cases) and the lowest rate in 2015 (DR 50.26/100,000 population; 36 cases), with fluctuations in the years 2007,2010 , and 2013 (Figure 1).

\section{DISCUSSION}

Leprosy is on the list of neglected diseases; it is associated with poverty indicators such as illiteracy, inadequate dwelling, disorganized urban growth, and ineffective healthcare services ${ }^{16}$. In this study, leprosy was detected predominantly in the 20-29year age group, which is in line with the results obtained in studies conducted in Betim, state of Minas Gerais, by Savassi et al. ${ }^{17}$, in the state of Tocantins by Monteiro et al. ${ }^{18}$, and in the state of Maranhão by Passos et al. ${ }^{19}$. In the municipality of Campos dos Goytacazes, state of Rio de Janeiro ${ }^{20}$, leprosy was more frequent in individuals aged $<15$ years. The higher DR of cases in age group 20-29 years in our study and the fact that men accounted for a higher percentage of cases in all age groups can likely be explained our analysis of data derived from the Brazilian Institute of Geography and Statistics ${ }^{21}$ that show a significant proportion of young male individuals in the labor market. On this subject, Lastória and Abreu ${ }^{22}$ stated that the clinical progression of leprosy requires a long incubation period and complex system of host-pathogen interactions, which may favor the infection of individuals that coincide with the most productive and socially interactive years.

Similar to our findings, other studies have reported the paucibacillary type in the age group $<15$ years and an association between the multibacillary types and an advanced age ${ }^{23-25}$. These results suggest that the municipality of Buriticupu is an 
TABLE 1: Demographic and clinical characteristics of new cases of leprosy, Buriticupu, Maranhão, 2003-2015.

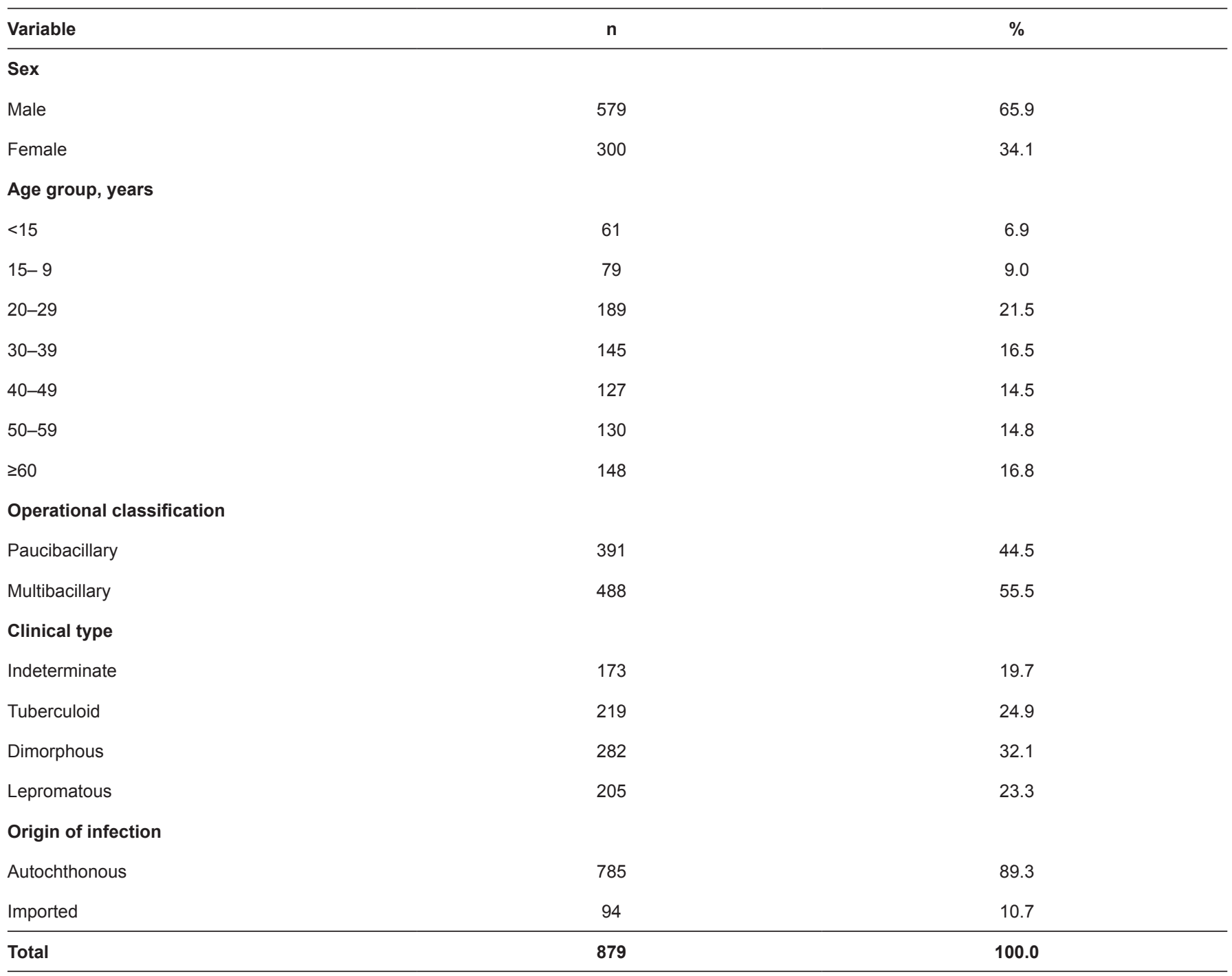

TABLE 2: New cases of leprosy based by age group and operational classification, Buriticupu, Maranhão, 2003-2015.

\begin{tabular}{|c|c|c|c|c|c|c|c|c|}
\hline \multirow{2}{*}{$\begin{array}{l}\text { Age group, } \\
\text { years }\end{array}$} & \multicolumn{4}{|c|}{ Operational classification } & \multirow{2}{*}{ Total } & \multirow{2}{*}{$\mathbf{p}^{*}$} & \multirow{2}{*}{ DR } & \multirow{2}{*}{$95 \% \mathrm{Cl}$} \\
\hline & $\mathbf{n}$ & $\%$ & $\mathbf{n}$ & $\%$ & & & & \\
\hline$<15$ & 41 & 67.2 & 20 & 32.8 & 61 & & 2.43 & $(1.77-3.32)$ \\
\hline $15-19$ & 44 & 55.7 & 35 & 44.3 & 79 & & 2.01 & $(1.45-2.79)$ \\
\hline $30-39$ & 74 & 51.0 & 71 & 49.0 & 145 & $<0.001$ & 1.84 & $(1.36-2.50)$ \\
\hline $40-49$ & 47 & 37.0 & 80 & 63.0 & 127 & & 1.34 & $(0.95-1.89)$ \\
\hline $50-59$ & 53 & 40.8 & 77 & 59.2 & 130 & & 1.47 & $(1.06-2.05)$ \\
\hline$\geq 60$ & 41 & 27.7 & 107 & 72.3 & 148 & & REF & 1.00 \\
\hline
\end{tabular}

*Tested with the Chi-square test of independence. CI: confidence interval; DR: detection rate; MB: multibacillary; PB: paucibacillary. 
TABLE 3: Cases of leprosy by sex and operational classification, Buriticupu, Maranhão, 2003-2015.

\begin{tabular}{|c|c|c|c|c|c|c|c|c|}
\hline \multirow{3}{*}{ Sex } & \multicolumn{4}{|c|}{ Operational classification } & \multirow{3}{*}{ Total } & \multirow{3}{*}{$p^{*}$} & \multirow{3}{*}{ DR } & \multirow{3}{*}{$95 \% \mathrm{Cl}$} \\
\hline & \multicolumn{2}{|c|}{ PB } & \multicolumn{2}{|c|}{ MB } & & & & \\
\hline & $\mathbf{n}$ & $\%$ & $\mathrm{n}$ & $\%$ & & & & \\
\hline Male & 208 & 35.9 & 371 & 64.1 & 579 & $<0,001$ & 1.64 & $(1.41-1.92)$ \\
\hline Female & 183 & 61.0 & 117 & 39.0 & 300 & & REF & 1.00 \\
\hline
\end{tabular}

*Tested with the Chi-square test of independence. CI: confidence interval; DR: detection rate; MB: multibacillary; PB: paucibacillary.

TABLE 4: Cases of leprosy by clinical type and sex, Buriticupu, Maranhão, 2003-2015.

\begin{tabular}{|c|c|c|c|c|c|c|c|c|}
\hline \multirow{3}{*}{ Clinical type } & \multicolumn{4}{|c|}{ Sex } & \multirow{3}{*}{ Total } & \multirow{3}{*}{$p^{*}$} & \multirow{3}{*}{ DR } & \multirow{3}{*}{$95 \% \mathrm{Cl}$} \\
\hline & \multicolumn{2}{|c|}{ Male } & \multicolumn{2}{|c|}{ Female } & & & & \\
\hline & $\mathrm{n}$ & $\%$ & $\mathrm{n}$ & $\%$ & & & & \\
\hline Undetermined & 87 & 50.3 & 86 & 49.7 & 173 & & REF & 1.00 \\
\hline Tuberculoid & 121 & 55.3 & 98 & 44.7 & 219 & & 1.10 & $(0.91-1.33)$ \\
\hline Dimorphous & 210 & 74.5 & 72 & 25.5 & 282 & ז ו & 1.48 & $(1.26-1.74)$ \\
\hline Lepromatous & 161 & 78.5 & 44 & 21.5 & 205 & & 1.56 & $(1.32-1.84)$ \\
\hline
\end{tabular}

*Tested with the Chi-square test of independence. $\mathbf{C l}$ : confidence interval; DR: detection rate.

150

100

50

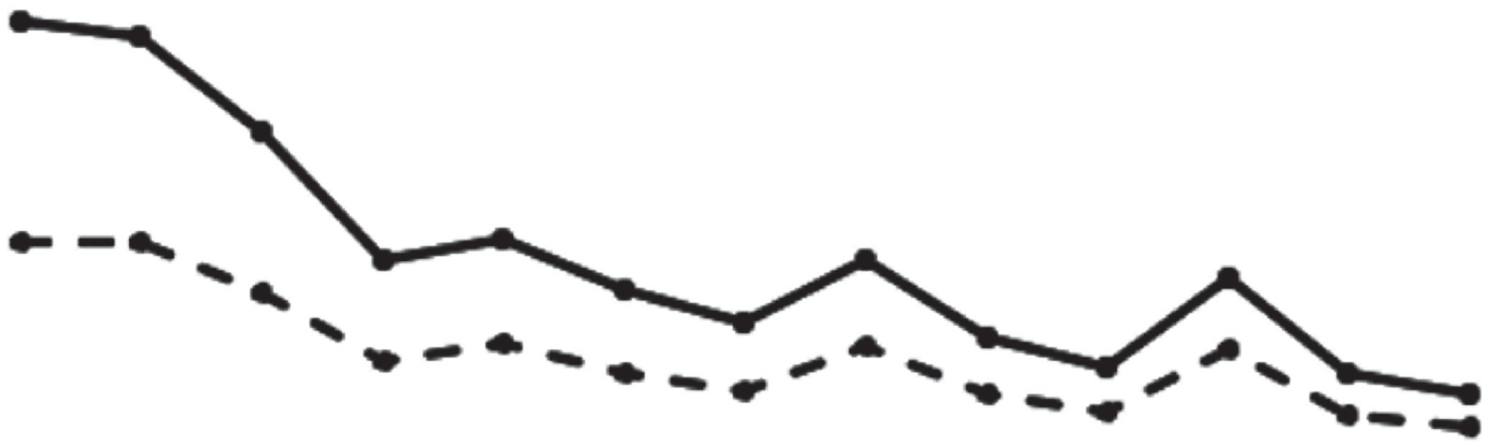

0

$\begin{array}{lllllllllllll}2003 & 2004 & 2005 & 2006 & 2007 & 2008 & 2009 & 2010 & 2011 & 2012 & 2013 & 2014 & 2015\end{array}$ $\rightarrow$ Coefficient of detection $\rightarrow-$ Number of leprosy cases

FIGURE 1: Historical series of the number of detected cases of leprosy and its detection rate in Buriticupu, Maranhão, $2003-2015$.

area of leprosy expansion with active transmission due to the maintenance of the bacilliferous sources and a persistence of a late diagnosis.

Our finding of the significant association between the male sex and the multibacillary types of leprosy $(p<0.001)$ are similar to those obtained by Passos et al. ${ }^{19}$ who reported that the probability of the multibacillary type in men was twice as high as in women. In contrast, a study conducted in Uberaba, Minas Gerais, found a significant association between the female sex and the multibacillary type of leprosy $(p<0.05)$, with the incidence of this type in women being four times higher than in $\operatorname{men}^{26}$. The diagnosis of the multibacillary type of leprosy and its high association with the male sex may be explained by the affected individuals not being aware of the initial symptoms and/or by their work not being affected. Therefore, these patients may delay in seeking healthcare interventions, and the disease is allowed to progress. 
The results of this study show that the leprosy DRs tended to decline from 2004 onward. However, several factors such as changes in municipal management, fluctuations in primary healthcare center teams, and a higher input from the active search of cases, may have affected the detection curve at three distinct moments, namely in 2007, 2010, and 2013.

Based on our analysis, we could determine that in Buriticupu, the goals that were originally set in the control program (a detection rate of $<100$ cases per 100,000 population and reducing disease transmission in individuals $<15$ of age years) were met. However, the identified DRs classify the municipality as hyperendemic for leprosy, according to the parameters defined by the Brazilian Ministry of Health ${ }^{5}$; this reflects the persistence of active transmission and a late diagnosis of the disease. In this context, disease control actions are ongoing, with the aim of reaching the goal set by the National Plan for the Elimination of Leprosy, i.e., a detection rate $<1$ case per 100,000 population $^{5,27}$.

The epidemiological dynamics of leprosy in Buriticupu are complex, and in general, disease occurrence remains associated with epidemiological determinants and historical factors despite epidemiological indicators pointing toward a reduction in the number of cases. Leprosy in Brazil has been associated with economic changes and serious environmental problems such as deforestation, which expanded the transmission of endemic diseases that were previously more common in rural areas, such as leprosy ${ }^{28}$.

Our findings appear to be related to the historical development of the surveyed area in the state of Maranhão, which has been marked by social and economic problems and where leprosy has been present ever since the current municipality of Buriticupu was only an area of agricultural colonization ${ }^{29}$. According to Dias, Dias, and Nobre $^{30}$, the social and economic indicators of a population should be discussed by health professionals because in addition to being risk factors for illness, they are a form of assessing the implementation of public health policies focused on endemic control according to the reality of each population. Ribeiro Júnior, Vieira, and Caldeira $^{31}$ highlighted the importance of integrating control measures into primary healthcare services to consolidate the control of leprosy; however, they point out challenges related to the autonomy of Brazilian municipalities to organize their health services as well as political and administrative challenges such as low qualification and uninformed municipal managers. They believe that the organizational and structural faults of the Brazilian Unified Public Health System cannot be overlooked and that factors such as the lack of physicians or the long wait times for an appointment with a specialist favor the transmission cycle of leprosy. Investing in measures that promote and strengthen decentralization, a greater qualification of multiprofessional teams, the ongoing improvement of information systems, structuring, and the continuity of an active search for cases are important for increasing the effectiveness of leprosy diagnosis, treatment, control, and eradication ${ }^{31,32}$.

In addition to contributing to the specific research field, the present study aimed at providing a benefit for and application of the obtained data in the study population. Moreover, we expect that our results will promote discussions among managers, social representatives, and healthcare teams in the region so that new goals in the control and eradication of leprosy in the municipality can be achieved.

\section{Acknowledgments}

We thank the professionals of the Buriticupu Municipal Health Department for their hospitality. We also thank the patients participating in this research for the valuable collaboration that allowed the performance of this work; last, we thank the brave settlers of Buriticupu.

\section{Conflict of Interest}

The authors declare that there is no conflict of interest.

\section{REFERENCES}

1. Opromolla PA, Laurenti R. Hansen's disease control in the State of São Paulo: a historical analysis. Rev Saude Publica. 2011;45(1):195203.

2. Rodrigues LC, Lockwood DN. Leprosy now: epidemiology, progress, challenges, and research gaps. Lancet Infect Dis. 2011;11(6):464-70.

3. World Health Organization. Global Leprosy Strategy 2016 -2020: Accelerating towards a leprosy-free world. India: WHO; 2016. Available from: http:/www.searo.who.int/entity/global_leprosy_ programme/documents/global_leprosy_strategy_2020/en/.

4. World Health Organization. Global leprosy update, 2014: need for early case detection. Geneva: WHO; 2015;90(36):461-74. Available from: http://www.who.int/lep/resources/who_wer9036/en/.

5. Brazil, Ministry of Health. Guidelines for surveillance, care, and elimination of leprosy as a public health problem 2016. $1^{\text {st }}$ ed. Brasília: Ministry of Health; 2016. Available from: https://pt.scribd. com/document/323388710/Diretrizes-para-vigilancia-atencao-eeliminacao-da-hanseniase-como-problema-de-saude-publica-2016.

6. SINAN/SVS/MS. Active registry: number and percentage, New cases of leprosy: number, rate and percentage, age group, operational classification, gender, degree of incapacity, examined contacts, by state and region, Brazil, 2015. Ministry of Health; 2014. Available from: http://portalarquivos.saude.gov.br/images/pdf/2015/julho/27/ Dados-2014---final.pdf.

7. Silva AR, Portela EGL, Matos WB, Silva CCB, Gonçalves EGR. Leprosy in the municipality of Buriticupu, State of Maranhão: active search among the student population. Rev Soc Bras Med Trop. 2007;40(6):657-60.

8. Silva AR, Matos WB, Silva CCB, Gonçalves EGR. Leprosy in Buriticupu, State of Maranhão: active search for cases in the adult population. Rev Soc Bras Med Trop. 2010;43(6):691-4.

9. Silva AR, Santos ARR, Santos ARR, Santos GMC, Silva VEB, Gonçalves EGR. Leprosy in Buriticupu, State of Maranhão: active search in the general population. Rev Soc Bras Med Trop. 2012;45(2):199-202.

10. Ridley DS, Jopling WH. A classification of leprosy for research purposes. Lepr Rev. 1962;33:119-28.

11. World Health Organization. Chemotherapy of leprosy for control programmes. Tech Rep Ser. 1982;675:1-33.

12. Organização Pan-Americana da Saúde. Enhanced global strategy for further reducing the disease burden due to leprosy: 2011-2015: operational guidelines (updated). Unidade Técnica Informação 
em Saúde, Gestão do Conhecimento e Comunicação da OPAS/ OMS - Represent do Bras; 2010. Available from: http://www. paho.org/bra/index.php?option $=$ com_docman\&task $=$ doc_ view\&gid $=1045 \&$ Itemid $=965$.

13. IBM Corp. IBM SPSS Statistics [Internet]. Armonk, NY; 2013.

14. Callegari-Jacques SM. Bioestatística - Princípios e Aplicações. Porto Alegre: Artmed; 2003. 264 p.

15. Schiaffino A, Rodríguez M, Pasarín MI, Regidor E, Borrell C, Fernández E. Odds ratio or prevalence ratio? Their use in crosssectional studies. Gac Sanit. 2003;17(1):70-4.

16. Hino P, Villa TCS, Cunha TN da, Santos CB dos. Spatial distribution of endemic diseases in Ribeirão Preto, São Paulo State. Cien Saude Colet. 2011;16:1289-94.

17. Savassi LCM, Bogutchi TRS, Oliveira APS, Modena CM. The influence of the compulsory internment in Leprosarium in the Quality of Life of Caregivers and Patients with Leprosy Sequel. Hansenol Int. 2009;34(2):21-31.

18. Monteiro LD, Martins-Melo FR, Brito AL, Lima $\mathrm{M}$ da $\mathrm{S}$, Alencar $\mathrm{CH}$, Heukelbach J, et al. Leprosy trends in Tocantins, a hyperendemic State in the North of Brazil, 2001-2012. Cad Saude Publica. 2015;31(5):971-80.

19. Passos CE de C, Silva AR da, Gonçalves E da G do R, Neiva FGC, Monteiro SG. Leprosy in Maranhão state: analysis of control strategies and the impact on epidemiological indicators. Hygeia. 2016;12(22):88-100.

20. Lobo JR, Barreto JCC, Alves LL, Crispim LC, Barreto L de A, Duncan LR, et al. Epidemiological profile of patients diagnosed with leprosy by contact exam in the municipality of Campos dos Goytacazes, RJ. Rev Bras Clínica Médica. 2011;9(4):283-7.

21. Brazilian Institute of Geography and Statistics. Demographic Census 2010. General characteristics of the population, religion and people with disabilities. Rio de Janeiro; 2012. Available from: http://biblioteca.ibge.gov.br/visualizacao/periodicos/94/cd_2010 religiao_deficiencia.pdf

22. Lastória JC, Abreu MAMM de. Leprosy: diagnosis and treatment. Diagn Trat. 2012;17(4):5-8.

23. Silva MEG da C, Souza CDF de, Silva SPC e, Costa FM da, Carmo RF do, Silva MEG da C, et al. Epidemiological aspects of leprosy in Juazeiro-BA, from 2002 to 2012. An Bras Dermatol. 2015;90(6):799-805.

24. Sousa AA de, Oliveira FJF de, Costa ACP de J, Neto MS, Cavalcante EF de O, Ferreira AGN. Adhesion to hansen's disease treatment for patients monitored at basic health units in Imperatriz-MA. Rev SANARE. 2013;12(1):6-12.

25. Souza CDF de, Rocha W de JSA da F, Lima RS de. Epidemiological profile of endemic leprosy in children under 15 years in the municipality of Juazeiro, Bahia, since 2003 until 2012. Hygeia. 2015;11(20):53-65.

26. Miranzi S de SC, Pereira LH de M, Nunes AA. Epidemiological profile of leprosy in a Brazilian municipality between 2000 and 2006. Rev Soc Bras Med Trop. 2010; 43(1):62-7.

27. Brazilian Ministry of Health. Epidemiological status of leprosy in Brazil: an analysis of select indicators in the 2001-2010 period. Health Brazil 2010: An analysis of the health situation and select evidence of the impact of health surveillance actions. 2013;44(35):185-202. Available from: http://portal.saude.gov.br/portal/arquivos/pdf/ cap_9_saude_brasil_2010.pdf.

28. Barreto ML, Teixeira MG, Bastos FI, Ximenes RA, Barata RB, Rodrigues LC. Successes and failures in the control of infectious diseases in Brazil: social and environmental context, policies, interventions, and research needs. Lancet. 2011;377(9780): 1877-89.

29. Silva AR. Agricultural colonization of Buriticupu: history told by those who lived it. 2nd ed. São Luís: EDUFMA; 2015. 304p.

30. Dias MCF de S, Dias GH, Nobre ML. Spatial Distribuition of hansen disease in the municipality of Mossoró/RN, using the Geographic Infromation System - (GIS). An Bras Dermatol. 2005;80:S289-94.

31. Ribeiro Júnior AF, Vieira MA, Caldeira AP. Epidemiological profile of leprosy in an endemic city for leprosy in the North of Minas Gerais. Rev Bras Clin Med. 2012;10(4):272-7.

32. Ministry of Health. Saúde Brasil 2010. An analysis of the health situation and select evidence of the impact of measures of health surveillance. 1st edition. Saúde Brasil 2010: an analysis of the health situation and selected evidence of the impact of health surveillance actions. Brasília: Editora MS; 2011. Available from: http://bvsms. saude.gov.br/bvs/publicacoes/saude_brasil_2010.pdf. 